\title{
Study on the Marketing Ability Training of Higher Professional \\ Personnel based on SAKT Mode
}

\author{
Tao $\mathrm{He}^{1, a^{*}}$, Ningchuan Jiang ${ }^{1, b}$ \\ ${ }^{1}$ School of Economics and Management, Chengdu Textile College, Chengdu, China \\ a1070027477@qq.com,_bJnc3000@163.com
}

\begin{abstract}
Keywords: Ability analysis; SAKT; Practical teaching; Professionalism; School-enterprise cooperation
\end{abstract}

\begin{abstract}
This paper builds a $S A K T$ mode to develop the marketing ability training of higher professional personnel. SAKT mode integrated four questions to solve: (A) teaching students in accordance of their aptitude (Student), (B) ability-oriented system (Ability), (C) marketing knowledge basis (Knowledge) and (D) effectively using the characteristics of a variety of teaching methods (Teaching Method). Based on analysis of "three knowledge communities and three modules of ability" of marketing course and seven elements of the ability goal including action, basic, interest, learning, innovation, team and year, the paper explored the mechanism innovation of cultivation including the school-enterprise cooperation, skill oriented and real education. We found that the practical teaching method system was the key integrated of teaching project, skills competitions and enterprises projects. And "Four Fusion One" mode of improve the professional ability is the result which fusing the abilities of learning, practice, cooperation and innovation. Applying this study, the college can develop more higher talents (professional personnel) who show the high professionalism, strong professional ability and advantages of development.
\end{abstract}

\section{Introduction}

The marketing quality and basic marketing skills has become the basic quality and the basic skills for all higher professional personnel(student). The marketing course can improve the student's professionalism to the overall quality of the employer of the companies needs significantly.

Marketing has completely changed in the last decade with the further entrenching of the Internet. Most of our education regarding marketing doesn't come in a classroom that is sponsored by or founded by the manufacturer [1]. International educational reform that aims at meeting the various challenges of globalisation and a knowledge-based economy. The dominant themes, trends and goals of modern education are the shared themes of curriculum adaptation, the emerging models of learning and innovation [2]. Some study show that there are differences and similarities in the lifestyles of young people who choose to study Marketing. The first, relating mainly to the identities assumed by students of daytime and nighttime that differ in their activities and more income. The second, by the increasing use and development of academic and social activities through the Internet of interest to young people today [3]. And some scholar relate the knowledge and experiences gained from a study to enhance Contemporary learning-centred(LC) in a first-year core marketing curriculum undertaken in a blended learning environment by large, diverse groups of business students [4].

The marketing system theory is very wide-ranging and complex which contains a number of knowledge communities and knowledge points including connotation of markets and marketing, 
marketing theory, marketing philosophy and consumer behavior research theory etc. Several teaching methods has already been adopted in the teaching of marketing as: case analysis, discussion, role-playing, and so on [5]. But the application is more dispersed, not systematic and not standardized, or more often depends on the teacher's individual judgment and self selection [6]. Analysis of the internal relations and the characteristics of knowledge, is a prerequisite for the application of a system of the teaching mode and teaching methods which can establish learning environments. Learning environments, learning and assessment approaches and assessment tasks each bring their own benefits, constraints and challenges to studying in a culturally diverse environment. Principles are presented for adoption by marketing educators in order to foster a vibrant, inclusive learning environment [7].

However, few studies have been focused on the clear marketing teaching mode or the practical teaching method system. So these issues are very worthy of study such as: (a) what relationship between marketing knowledge and practice ability of students; (b) how to integrate the the various teaching methods of marketing to be a system? (c) how to train and improve the students' professional ability effectively? This paper revealed the relationship between marketing knowledge and practice ability and analysis of "three knowledge communities and three modules of ability" of marketing course. What's more, we discuss SAKT mode to develop the marketing ability training of higher professional personnel and the practical teaching method system and "Four Fusion One" mode to improve professional ability. Finaly, some suggestions get.

\section{Preliminary}

A. Three knowledge communities of marketing. Three knowledge communities include the marketing principles, marketing practices and marketing foundation. Marketing practices is the goal, the principles community of marketing is a dynamic system and the marketing foundation community is supporting system of marketing.

The principles of Marketing refers to the theory of marketing disciplines and basic content such as the connotation of markets and marketing, the marketing philosophy, the marketing systems, the marketing environment analysis and consumer behavior research theory etc. Marketing practice include the overall strategy of the enterprise, enterprise business strategy, business portfolio strategy and the enterprise planning. And the analysis of competitors and competitive strategy, competitive strategy, marketing strategy, market competition strategy of different competitive status. And STP strategy(market segmentation, target market and positioning) Especially marketing strategy including the marketing mix of 4P's: product strategy, pricing strategy, marketing strategy and marketing strategy, brand strategy and packaging [8]. The marketing foundation community includes that market survey and forecast methods and marketing management including the preparation and execution of marketing plan and organization design.

B. Three modules of ability of marketing- Ability Analysis. Ability module is the cornerstone of the curriculum reform, the teaching content corresponding to support different ability modules for student's different marketing skills. Three modules of ability include the marketing Basic module, improve module and expand module of ability. The basic module includes these abilities of marketing environment analysis, market research, market forecast, market (customer) analysis, target market selection, market positioning and marketing mix strategy. The improve module includes these abilities of the determination of the marketing strategy, the control ability of marketing and international marketing strategy. The expand module of ability includes these abilities of the customer management, logistics management and the ability of specific marketing 
strategy. The teacher can choose different capacity modules according to the needs of training objectives flexible [9]. And the basic module is the core module of marketing ability teaching.

The ability module can help the teacher get the organic integration and optimization of teaching content system. And it can be selected according to the characteristics of students ability and target.

\section{Results and Discussion}

A. The SAKT Mode (The System of Ability-Knowledge-Teaching Method of Marketing). This study attempts to build a $S A K T$ mode to develop the marketing ability training of higher Professional personnel. SAKT mode integrates four questions to solve: (A) teaching students in accordance of their aptitude (Student), (B) ability oriented system (Ability), (C) marketing knowledge is the basic (Knowledge) and (D) effectively using the characteristics of a variety of teaching methods (Teaching Method). Take the student as the main body of teaching, and teaching them according to their aptitude. Teaching goal is ability oriented and ability training depends on the knowledge foundation and the characteristic teaching method combined, as shown in Fig .1.

This research shows that: the ability to meet the market demand of the students should be comprehensive and integrated in today's era. To achieve the ability need three aspects and 7 elements: ability factor (Basic \Learn\Innovation), ability training path (Action) and ability training mode (Interest $\mid$ TeamlYear). Thus, Ability $=\mathrm{A}+\mathrm{B}+\mathrm{I}+\mathrm{L}+\mathrm{I}+\mathrm{T}+\mathrm{Y}$, as shown in Table 1.

The core work should establish an open, multi-channel, practical teaching method system based on practical teaching, as shown in Fig .2, Fig .3.

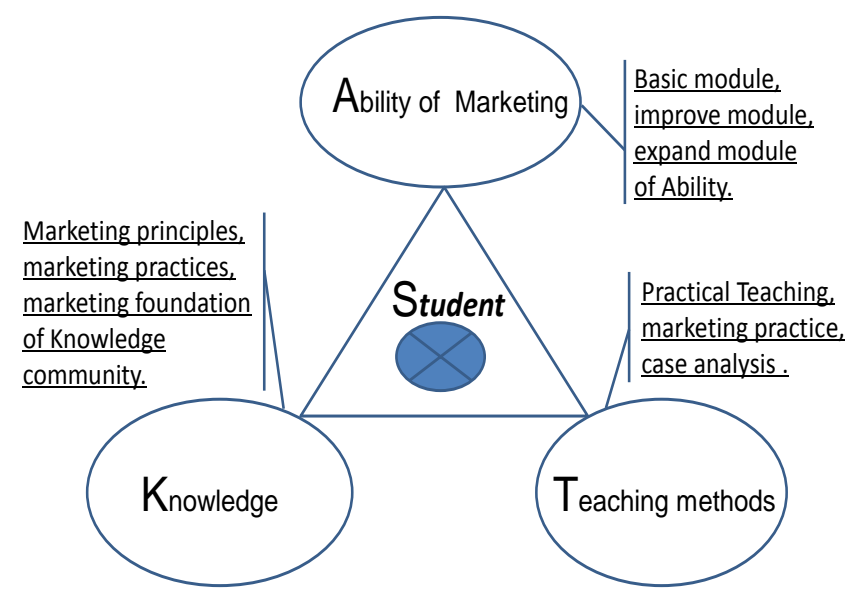

Table $1 \quad 7$ elements of Ability Goal

Figure 1. SAKT mode of training higher Professional personnel' skills.

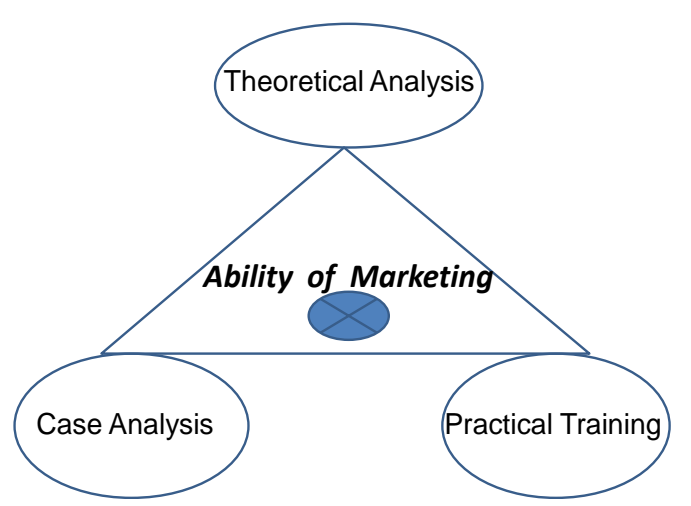

Figure 2. Triangle of training marketing skills

\begin{tabular}{|c|l|l|l|}
\hline \multirow{2}{*}{$\begin{array}{c}\text { Serial } \\
\text { number }\end{array}$} & \multicolumn{3}{|c|}{ three aspects / 7 elements of Ability Goal } \\
\cline { 2 - 4 } & Ability factor & $\begin{array}{c}\text { Ability training } \\
\text { path }\end{array}$ & $\begin{array}{c}\text { Ability training } \\
\text { mode }\end{array}$ \\
\hline 1 & $/$ & Action & $/$ \\
\hline 2 & Basic & $/$ & Interest \\
\hline 3 & Learn & $/$ & Team \\
\hline 4 & Innovation & $/$ & Year \\
\hline
\end{tabular}

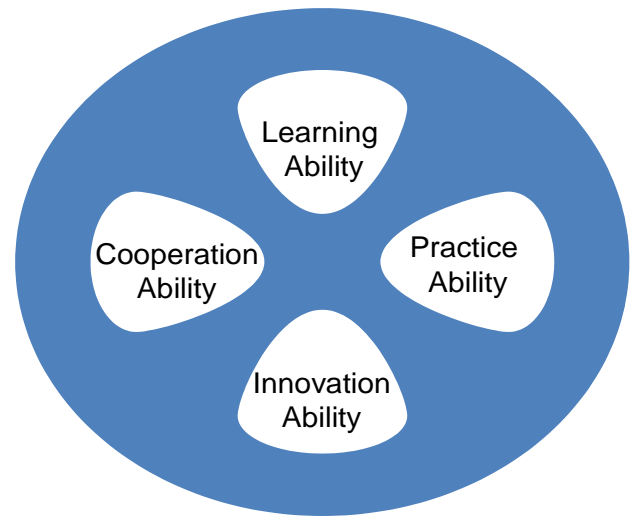

Figure 3. "Four Fusion One" mode of improve students ' professional ability 
B. Analysis of the Basic Concept and Basic Theory. Objective: to master the basic theories of marketing, improve the theoretical level of the students. Ability type: basic module, inquiry learning ability, analysis ability. Optimization of teaching methods: the inductive thinking, get the concept(the multimedia teaching of "MOOCS"), Scientific inquiry and mnemonics.

C. Marketing Practice and Case Analysis. Objective: to share the enterprise marketing experience, the combination of theory and practice. Ability type: basic module and improve module-- research ability, expression ability, independent analysis, problem solving ability, cooperation ability and creative thinking. Optimization of teaching method: the cooperative learning,the simulation scene teaching method. the role-playing, the divergent thinking training method and group survey.

D. The "Real"Practice Teaching System. Objective: to enhance students' practical ability, to master and understand the theory in practice. Practical teaching methods mainly include: sand-table simulation teaching, enterprise project(from promote school-enterprise cooperation), marketing skills competition, scene teaching, market investigation, team activities, computer simulation, practice base, simulation fair and other marketing activities. Ability type: improve module and expand module -- exploring ability, analysis ability, the ability of social communication and cooperation ability, learning, collaborative learning ability, expression ability, independent analysis ability, problem solving ability and creative thinking ability. Optimization of teaching method: the enterprise project, marketing skills competition, group survey, the sand-table simulation study, the role-playing and inquiry training.

Based on the above discussion, the analysis results of the system of ability-knowledge-teaching method of marketing have been get, as shown in Table 2. Adopting project teaching method and integrate teaching situation and work areas to get a combination of "teaching, learning and doing" is very effective. The student's professionalism is greatly improved and their ability can be comprehensive performance which fusing the four abilities of learning, practice, cooperation and innovation. Thus "Four Fusion One" mode of improve the professional ability is the result, as shown in Fig.3.

The effect of the application of this teaching system in the course of marketing is very comprehensive. As the final results, through the training of SAKT mode and "Four Fusion One" mode obtained this study, college students can become the professionals with career mobility of marketing positions.

Table 2 The System of Ability-Knowledge-Teaching Method of Marketing

\begin{tabular}{|c|c|c|c|c|c|c|c|}
\hline \multirow{2}{*}{ Type } & \multirow{2}{*}{ Item } & \multicolumn{3}{|c|}{ Ability } & \multicolumn{3}{|c|}{ Knowledge Community } \\
\hline & & $\begin{array}{l}\text { Basic } \\
\text { Module }\end{array}$ & $\begin{array}{l}\text { Improve } \\
\text { Module }\end{array}$ & $\begin{array}{l}\text { Expand } \\
\text { Module }\end{array}$ & $\begin{array}{l}\text { Marketing } \\
\text { Principles }\end{array}$ & $\begin{array}{l}\text { Marketing } \\
\text { Practices }\end{array}$ & $\begin{array}{l}\text { Marketing } \\
\text { Foundation. }\end{array}$ \\
\hline \multirow{3}{*}{$\begin{array}{l}\text { Teaching } \\
\text { Method }\end{array}$} & $\begin{array}{l}\text { Practical } \\
\text { Teaching }\end{array}$ & $\begin{array}{l}\text { case analysis, } \\
\text { market } \\
\text { investigation }\end{array}$ & $\begin{array}{l}\text { Sand-table } \\
\text { simulation, } \\
\text { scene teaching, } \\
\text { market } \\
\text { investigation, } \\
\text { MOOCs, } \\
\text { simulation fair }\end{array}$ & group survey & $\begin{array}{l}\text { case analysis, } \\
\text { get the concept, } \\
\text { scientific } \\
\text { inquiry, } \\
\text { MOOCs, } \\
\text { mnemonics }\end{array}$ & $\begin{array}{l}\text { Sand-table } \\
\text { simulation, } \\
\text { scene teaching, } \\
\text { market } \\
\text { investigation, } \\
\text { simulation fair, } \\
\text { role-playing }\end{array}$ & $\begin{array}{l}\text { inductive } \\
\text { thinking, } \\
\text { get the concept, } \\
\text { MOOCs, } \\
\text { scientific } \\
\text { inquiry, } \\
\text { mnemonics }\end{array}$ \\
\hline & $\begin{array}{l}\text { marketing } \\
\text { practice }\end{array}$ & $\begin{array}{l}\text { market } \\
\text { investigation }\end{array}$ & $\begin{array}{l}\text { enterprise } \\
\text { project, } \\
\text { marketing skills } \\
\text { competition, } \\
\text { computer } \\
\text { simulation, } \\
\text { practice base }\end{array}$ & $\begin{array}{l}\text { enterprise } \\
\text { project, } \\
\text { Simulation } \\
\text { company,team } \\
\text { activities }\end{array}$ & $\begin{array}{l}\text { inductive } \\
\text { thinking }\end{array}$ & $\begin{array}{l}\text { enterprise } \\
\text { project, } \\
\text { marketing skills } \\
\text { competition, } \\
\text { group survey, } \\
\text { sand-table } \\
\text { simulation, }\end{array}$ & $\begin{array}{l}\text { market } \\
\text { investigation, } \\
\text { computer } \\
\text { simulation,pract } \\
\text { ice base }\end{array}$ \\
\hline & $\begin{array}{c}\text { case } \\
\text { analysis }\end{array}$ & $\begin{array}{l}\text { discussion, case } \\
\text { analysis }\end{array}$ & $\begin{array}{l}\text { cooperative } \\
\text { learning, } \\
\text { group survey }\end{array}$ & $\begin{array}{l}\text { divergent } \\
\text { thinking }\end{array}$ & $\begin{array}{l}\text { discussion, } \\
\text { case analysis }\end{array}$ & $\begin{array}{l}\text { case analysis, } \\
\text { divergent } \\
\text { thinking }\end{array}$ & $\begin{array}{l}\text { discussion, } \\
\text { case analysis }\end{array}$ \\
\hline
\end{tabular}




\section{Conclusion}

A. The ultimate goal of this training system is the ability. Lots of practice has proved that the above marketing ability training mode (SAKT) of higher vocational talents or the system(of ability--teaching content--teaching method ) can effectively enhance the effectiveness of teaching and improve teaching quality and quickly promote the training of students ' practical ability and innovation ability.

B. Marketing course examination must carry out a comprehensive reform. To implement the interactive teaching styles and methods of taking students as the main body. Determine the comprehensive examination of practice ability as the goal, to establish open, whole course evaluation system to promote the all-round development of students' personality and ability.

C. It should adopt the multimedia teaching of "MOOCS" in the teaching system. Since the 1990s massive open online courses (MOOCs) have offered web - based learning on a large scale and with open access [10]. To make MOOCs and other multimedia, create videos, course ware, business cases, network resources, the second classroom and enterprise base to integrate the teaching system. D. To establish the "real" practice teaching system or "Four Fusion One" mode, the enterprise marketing programs must be put into the classroom to build marketing live. If we promote school-enterprise cooperation and give full play to the advantage of internal and external education resource, the target can realize which cultivate more higher professional personnel who needed by enterprise for his high professionalism and strong professional ability.

\section{References}

[1] Brandyberry, Tschanen, "EDUCATION FROM THE TOP DOWN," Motor Age, 133 (10) (2014) 14-16,.

[2] Wing On Lee, "Learning for the future: the emergence of lifelong learning and the internationalisation of education as the fourth way?," Educational Research for Policy and Practice, 11 (1)(2012) 53.

[3] Uribe Arévalo, Abel Eduardo, Barreto, Idaly, "The Identity of Students Choosing Marketing Programs," Suma Psicologica, 16 (2)(2009) 27.

[4] Tania von der Heidt, "Enhancing learning-centeredness in marketing principles curriculum," Australasian Marketing Journal (AMJ), 21 (4) (2013)16.

[5] SAES "2013 annual report of China education research frontier and hot issues," Educational Research . China, 2(2014) 21.

[6] SAES "2012 annual report of China education research frontier and hot issues," Educational Research . China, 2(2013) 15.

[7] Allison Ringer, Michael Volkov, Kerrie Bridson, “C.U.L.T.U.R.E.: marketing education in the age of cultural diversity,” Education + Training, 56 (6)(2014) 506.

[8] Philip Kotler, Gary Armstrong, "PRINCIPLES of MARKETING," China Renmin University Press, Beijing, 2010.

[9] Jiang Dayuan, “A new study of Vocational Education," Educational Science Publishing House, Beijing, 2007.

[10] Lee Wilson, Anatoliy Gruzd, "MOOCs - international information and education phenomenon?” Bul. Am. Soc. Info. Sci. Tech., 40 (5)( 2014)39. 